\title{
Metallic corneal foreign bodies: an occupational health hazard
}

\section{Corpos estranhos metálicos na córnea: um problema de saúde ocupacional}

\author{
Zeynep Gursel Ozkurt ${ }^{1}$, Harun Yuksel ${ }^{1}$, Gunay Saka ${ }^{1}$, Hande Guclu², Sina Evsen², Selahattin Balsak²
}

\section{ABSTRACT}

Purpose: To analyze the risk factors, outcomes, demographic characteristics, and attitudes of workers with metallic corneal foreign body (FB) injury.

Methods: One hundred consecutive patients who presented with a metallic corneal FB to the eye clinic at Diyarbakir Training and Research Hospital were evaluated. The patients completed a questionnaire and were examined to determine features of the injury.

Results: All patients were male. The mean age was $32.46 \pm 1.03$ years. Fifty-five percent of the patients were unregistered workers, $59 \%$ were working in the metal industry sector, and $65 \%$ injuries resulted from metal cutting. Protective goggles were available in the workplace of $64 \%$ patients. However, $57 \%$ patients were not wearing goggles when the accident occurred, and $43 \%$ were injured despite goggle use. Most patients (52\%) attempted to remove FBs by themselves. FBs were located in the central zone of the cornea in $16 \%$ patients. Rust marks remained after FB removal in $26 \%$ patients. Corneal scars from previous FB injuries were present in $58 \%$ patients. Only $8 \%$ workplaces provided compensation for physician visits for occupation-related illnesses.

Conclusions: Workplaces with a high risk for eye injuries should increase their protective measures, and educational programs should be implemented for both workers and occupational physicians. The government should enforce laws regarding unregistered workers in a better manner.

Keywords: Corneal injuries; Ocular foreign bodies; Eye injuries; Occupational health; Accidents, occupational

\section{RESUMO}

Objetivo: Analisar os fatores de risco, resultados, características demográficas dos trabalhadores e atitudes em relação à lesão por corpo estranho metálico na córnea.

Métodos: Foram avaliados cem pacientes consecutivos que se apresentaram com corpo estranho metálico na córnea à clínica oftalmológica do Diyarbakir Training and Research Hospital. Um questionário foi respondido e as características da lesão foram anotadas.

Resultados: Todos os pacientes eram do sexo masculino. A idade média foi de $32,46 \pm 1,03$ anos. Cinquenta e cinco por cento dos pacientes eram trabalhadores não registrados. Cinquenta e nove por cento dos pacientes estavam trabalhando no setor da indústria metal, $65 \%$ das lesões resultaram de corte de metal. A presença de óculos de proteção no local de trabalho foi de $64 \%$. Cinquenta e sete por cento dos pacientes não estavam usando óculos de proteção no momento do acidente, e 43\% sofreram a lesão, apesar do uso óculos de proteção. Cinquenta e dois por cento dos pacientes tentaram remover o corpo estranho por si só. Dezesseis por cento dos corpos estranhos foram na zona central da córnea. Um depósito de ferrugem permaneceu após a remoção do corpo estranho em $26 \%$ dos pacientes. Cinquenta e oito por cento dos pacientes tinham cicatrizes na córnea por causa de lesões por corpo estranho anteriores. Os locais de trabalho que proporcionaram remuneração por visita médica relacionada à ocupação foram de apenas $8 \%$.

Conclusões: Locais de trabalho de alto risco devem ser detectados e medidas de proteção devem ser aumentadas. Os programas educacionais devem ser implementados para os trabalhadores e médicos do trabalho. As leis sobre trabalhadores sem carteira assinada deve ser melhor fiscalizadas pelo governo.

Descritores: Córnea/lesões; Corpos estranhos oculares; Lesões oculares; Saúde ocupacional; Acidentes de trabalho

\section{INTRODUCTION}

A superficial corneal foreign body (FB) is the most common and preventable eye injury ${ }^{(1)}$. Metallic corneal FBs resulting from occupational accidents are often seen in construction and metal industry workers ${ }^{(2)}$. FBs can decrease the quality of vision by causing scars on the visual axis and secondary infections ranging from keratitis to endophthalmitis ${ }^{(3,4)}$. The health care costs for these injuries are another problem as they create an economic burden ${ }^{(5)}$.

Prevention of FB accidents and their potentially serious consequences are certainly possible, and the investment in their prevention is easily justified. Wearing appropriate protective goggles prevents about two-thirds of these accidents ${ }^{(6)}$. In addition to the use of personal protective measures, it is important to improve workplace standards and provide appropriate training for supervisors ${ }^{(7)}$.

Approximately $36 \%$ workers in Turkey are unregistered ${ }^{(8)}$. Unregistered workers do not qualify for government-funded health care after an occupational accident nor do they take advantage of their legal rights. In this study, we investigated the demographic characteristics, eye protection measures, approaches to FBs, and the level of knowledge about corneal FBs in a working population in Turkey.

\section{METHODS}

This study was approved by the hospital's institutional review board and adhered to the tenets of the Declaration of Helsinki. This prospective study evaluated 100 consecutive patients who presented with metallic corneal FBs to the eye clinic at Diyarbakir Training and Research Hospital between December 2012 and May 2013. Verbal consent was obtained from the patients before they completed the questionnaire.

Patients were evaluated with a silt-lamp biomicroscope. FBs and rust rings were removed using a 26-gauge needle under topical anesthesia. A topical antibiotic treatment (Tobramycin, four times 
a day) was prescribed after FBs were removed. The locations of the removed FB, rust marks, and any existing corneal scars from previous FBs were noted.

We recorded demographic information for each patient, which included age, gender, education, and type of social insurance. The following data also were obtained through our questionnaire: business sector and occupation at the time of incident, number of years of work in the present sector, time between the incident and first visit to an ophthalmologist, number of previous similar eye injuries, availability of protective goggles at work, protective goggle use during the incident, attempted FB removal by the patient, technique used if self-removal was attempted, the number of workers in the workplace, and presence of an occupational physician. To determine a worker's level of knowledge about corneal FB injuries, we asked whether they understood that repetitive FB injuries can cause serious visual impairment and FB removal by themselves can cause serious and infection.

Statistical analyses were performed with Statistical Program for Social Science (SPSS) version 15 (SPSS, Chicago, Illinois, USA). The statistical calculations included descriptive statistics, chi-square test, and Spearman-Brown correlation. The data are presented as the mean \pm standard deviation.

\section{RESULTS}

We examined 100 patients who were diagnosed with a metallic corneal FB. All patients were male and had a mean age of $32.46 \pm 1.03$ years (age range: 14-57 years; Table 1). Six percent of patients had not received formal education, 56\% had completed primary school, 23\% had completed secondary school, $15 \%$ had graduated from high school or an equivalent institution. Forty-eight percent of the patients had a green card (a document given to low-income individuals without social insurance to allow them to use the public health care service in Turkey) and 7\% had no social insurance; thus, 55\% patients were unregistered workers, whereas only $45 \%$ were registered.

Most patients (59\%) were working in the metal industry sector, $25 \%$ were working in the construction sector, and $8 \%$ were working in automotive repair sector (Table 2). Most injuries (65\%) occurred when the patient was cutting metal (65\%), 22\% occurred with welding, and $13 \%$ had an unknown origin (Table 3 ). The number of FB injuries increased significantly with number of years at work in the metal industry and construction sectors $(p<0.001, p=0.005)$. Sixty-four percent of the patients reported that protective goggles were available in their workplace; however, $57 \%$ were not wearing goggles at the time the accident occurred, and $43 \%$ were injured despite goggle use. There was no significant correlation between the education level and goggle use $(p=0.470)$.

We examined the patient's knowledge about corneal FBs and his approach to treatment. The mean duration between the injury and the first visit to an ophthalmologist was $2.16( \pm 0.26)$ days and ranged between 0 and 21 days. We found that 52\% patients attempted FB removal by themselves. The materials used for the removal were currency notes (31\%), napkins (7\%), a cloth (4\%), and miscellaneous items (10\%) such as a needle or toothpick, which can cause further injury (Table 4). One patient presented with a deep central corneal scar that caused a secondary infection after he had removed the FB by himself. There was no significant correlation between the education level and whether patients attempted to remove FBs by themselves, or between understanding the potential harm in self-removal and understanding repetitive FB injuries can harm visual acuity $(p=0.079$, $p=0.435, p=0.329$ ).

Only $8 \%$ workplaces provided an occupational physician service; however, the presence of an occupational physician in the workplace did not affect the availability of protective goggles $(p=0.580)$, the workers' attitudes about wearing goggles $(p=0.341)$, whether workers attempted to remove FBs by themselves $(p=0.284)$, or understanding the harm of self-removal of FBs $p=0.764$ ).
Table 1. Distribution of patients by age group in 15-year age intervals

\begin{tabular}{lc}
\hline Age group (years) & Percentage \\
\hline $14-29$ & $42 \%$ \\
$30-44$ & $42 \%$ \\
$45-60$ & $16 \%$ \\
\hline
\end{tabular}

Table 2. Occupation sectors

\begin{tabular}{lc}
\hline Sector & Percentage \\
\hline Metal industry & $59 \%$ \\
Construction industry & $25 \%$ \\
Automotive repair & $8 \%$ \\
Other & $8 \%$ \\
\hline
\end{tabular}

Table 3. İnjury mechanisms

\begin{tabular}{lc}
\hline İjury mechanism & Percentage \\
\hline Metal cutting & $65 \%$ \\
Welding & $22 \%$ \\
Unknown origin & $13 \%$ \\
\hline
\end{tabular}

Table 4. Materials used for self-removal

\begin{tabular}{lc}
\hline Material & Percentage \\
\hline Paper money & $31 \%$ \\
Napkins & $7 \%$ \\
A piece of cloth & $4 \%$ \\
Other & $10 \%$ \\
\hline
\end{tabular}

The locations of the FBs were central (16\%), paracentral (61\%), and peripheral (23\%). Rust marks were present in $26 \%$ patients after FBs were removed. Corneal scars due to previous FB injuries were present in 58\% patients and were located in the central (5\%), paracentral (42\%), and peripheral (11\%) regions.

\section{DISCUSSION}

Corneal injury due to a metallic FB is a common occupational health injury in Turkey and worldwide. Occupational injury by corneal FB comprises $35 \%-58 \%$ of all ocular trauma ${ }^{(9,10)}$, and more frequently affects young men ${ }^{(11)}$. These preventable injuries cause additional burden on the national economy, adjustment problems, and psychological morbidity ${ }^{(5,12)}$.

In a study conducted in Turkey, metal fragments caused 37\% of all superficial corneal FB injuries, but the occupational injury ratio and the causes of injury were not defined in that study ${ }^{(13)}$. In our study, occupational injuries occurred during metal cutting (65\%) or welding (22\%), whereas 13\% had an unknown origin. Metal cutting and welding are frequent tasks in the metal industry; hence, most FB eye injuries occurred in this sector (59\%), which was followed by the construction sector. In a similar study, 70\% corneal FB injuries occurred in the metal cutting industry(14). In a Canadian study, 21\% eye injuries occurred during welding ${ }^{(15)}$. Thus, the people working in these sectors comprise the largest risk group.

In our patient population, 52\% patients attempted to remove the FBs themselves using materials that can damage and infect the 
cornea. In a study conducted by Filho et al., several microorganisms apart from the normal conjunctival flora were isolated from 20\% conjunctival swabs of patients with corneal $\mathrm{FBs}^{(4)}$. In a similar study, 14\% positive bacteria cultures were obtained from patients with corneal $\mathrm{FBS}^{(5)}$. Corneal FBs themselves can spread infections, and self-removal of an FB with contaminated and potentially traumatic materials can increase the risk of corneal infections. These secondary corneal infections affect the quality of vision and can cause corneal scarring. In one of our patients, a deep corneal scar caused vision loss that resulted from a corneal abscess that formed after self-removal of an FB. In an Australian study that included 100 patients with metallic corneal FBs, one patient presented with bacterial keratitis, although it was not indicated whether the patient attempted FB removal|(11).

Metallic FBs usually leaves a rust ring in the cornea often causes a white scar to form that can decrease visual quality. The appearance of a rust ring indicates an FB was embedded in the cornea for $>12-24 \mathrm{~h}^{(16)}$ Therefore, visiting an ophthalmologist after an injury as soon as possible is crucial. Among our patients, the mean duration between the injury and their first visit to an ophthalmologist was 2.16 ( \pm 0.26$)$ days after the injury. A rust ring remained in $26 \%$ patients and a corneal white scar attributed to a previous FB was observed in 58\% patients. The high frequency of scarring observed in our patients likely resulted from the delay in seeking treatment from an ophthalmologist and the attempt of removing the FB with traumatic materials.

Using protective goggles, especially those with top and side shields, may have prevented two-thirds of these FB injuries ${ }^{(6)}$. Despite wearing goggles, 43\% patients sustained injuries. In a similar study, $45 \%$ patients sustained an eye injury while wearing some form of eye protection $^{(11)}$. In this context, new designs should be implemented and workplace standards should be adjusted to increase the protective capabilities of goggles ${ }^{(7)}$.

According to the current occupational health and safety board regulations in Turkey, an occupational physician is necessary in sectors that employ at least 50 workers. The workplaces of only $8 \%$ patients in the present study had an occupational physician. The dominance of small-scale workplaces and 55\% workers being unregistered might explain this low ratio. Unfortunately, the presence of an occupational physician has not been effective for the procurement of protective goggles at workplaces or the attitudes of workers toward goggle use. In addition, the presence of an occupational physician has not increased the workers' level of knowledge about ocular safety. In addition, no correlation was found between education and the knowledge of the subject. According to these data, occupational physicians should be informed about the importance of preventative measures against eye injuries, and they should inform workers about the subject without considering the workers education status.

In Turkey, approximately 36\% employees are unregistered ${ }^{(8)}$. In the present study, this percentage was even higher at 55\%. These unregistered workers are unable to take advantage of legal rights for accidents occurring at work. In addition, workers do not have social insurance and are ineligible for free health care. This situation can force workers to remove the FBs by themselves rather than seek care from an ophthalmologist.

\section{CONCLUSION}

Workplaces with a high risk for corneal injury should be identified, occupational physicians and workers should be educated about such eye injuries, and eye protective measures should be increased. Furthermore, the necessary legal arrangements should be made to decrease the number of unregistered workers.

\section{ACKNOWLEDGMENT}

We are grateful to Dicle University DUBAP for their sponsorship of the English editing of this manuscript.

\section{REFERENCES}

1. Woo JH, Sundar G. Eye injuries in Singapore-Don't risk it. Do more. A prospective study. Ann Acad Med Singapore. 2006;35(10):706-18.

2. Welch LS, Hunting KL, Mawudeku A. Injury surveillance in construction: eye injuries. Appl Occup Environ Hyg. 2001:16(7):755-62.

3. DeBroff BM, Donahue SP, Caputo BJ, Azar MJ, Kowalski RP, Karenchak LM. Clinical characteristics of corneal foreign bodies and their associated culture results. CLAO J. 1994; 20(2):128-30.

4. Macedo Filho ET, Lago A, Duarte K, Liang SJ, Lima AL, Freitas D. Superficial corneal foreign body: laboratory and epidemiologic aspects. Arq Bras Oftalmol. 2005:68(6):821-3.

5. Fong LP. Eye injuries in Victoria, Australia. Med J Aust. 1995;162(2):64-8.

6. Gumus K, Karakucuk S, Mirza E. Corneal Injury from a metallic foreign body: an occupational hazard. Eye Contact Lens. 2007:33(5):259-60.

7. Lipscomb HJ, Dement JM, McDougall V, Kalat J. Work-related eye injuries among union carpenters. Appl Occup Environ Hyg. 1999;14(10):665-76.

8. Turkiey Istatistik Kurumu. [cited 2013 Sep 6]. Available from: http://www.tuik.gov.tr/ PreHaberBultenleri.do?id=13483

9. Nicaeus T, Erb C, Rohrbach M, Thiel HJ. [An analysis of 148 outpatient treated occupational accidents]. Klin Monatsbl Augenheilkd. 1996;209(4):A7-11. German.

10. Voon LW, See J, Wong TY. The epidemiology of ocular trauma in Singapore: perspective from the emergency service. Eye (Lond). 2001;15(Pt 1):75-81.

11. Ramakrishnan $T$, Constantinou M, Jhanji V, Vajpayee RB. Corneal metallic foreign body injuries due to suboptimal ocular protection. Arch Environ Occup Health. 2012:67(1):48-50.

12. Alexander DA, Kemp RV, Klein S, Forrester JV. Psychiatric sequelae and psychosocial adjustment following ocular trauma: a retrospective pilot study. Br J Ophthalmol. 2001; 85(5):560-2.

13. Yiğit $\mathrm{O}$, Yürüktümen $A$, Arslan S. Foreign body traumas of the eye managed in an emergency department of a single-institution. Ulus Travma Acil Cerrahi Derg. 2012;18(1):75-9.

14. Nepp J, Rainer G, Krepler K, Stolba U, Wedrich A. [Etiology of non-penetrating corneal injuries]. Klin Monatsbl Augenheilkd. 1999;215(6):334-7. German

15. Reesal MR, Dufresne RM, Suggett D, Alleyne BC. Welder eye injuries. J Occup Med. 1989;31(12):1003-6

16. Casser $L$, Fingeret $M$, Woodcome $H$. Atlas of primary eyecare procedures. New York: Appleton Lange; 1990. 